\title{
Paleoclimatical significance of the paleosol levels occurring in the Miocene-Pleistocene stratigraphy of the Manonga-Wembere Valley in
} Central Tanzania

Ministry of Energy and Minerals P. O. Box 2000, Dar Es Salaam, Tanzania. Email:kafumu@mem.go.tz and kafumu@yahoo.com

\begin{abstract}
Micromorphological characteristics of four paleosol levels of the Manonga - Wembere deposits in Central Tanzania indicate periods of wetter climate in the Pliocene than at present. The stratigraphy of the studied section shows a series of lacustrine calcareous clay sediments alternating with gravel, sand and silt. The sediments are believed to have been deposited in the Manonga - Wembere paleolake environment. Paleosols intercalate these sediments and were formed when stable landscapes developed on former lake beds during regression periods. Micromorphological features of the paleosols indicate strong clay illuviation of red to yellow typic clay coating and some $\mathrm{Fe}$-Mn hydoxide hypocoatings in voids and channels. The groundmass consists of either an accumulation of bioturbated yellow to red clay coating fragments or an argillic red to yellow groundmass of clay mass. Such an illuviation and its associated groundmass is comparable to intense clay illuviation fronts that are found in present-day calcareous sediments of warm and wet climates. The paleosol levels therefore represent wetter climatic conditions than today in the area during the Lower Pliocene.
\end{abstract}

\section{Introduction}

The Manonga - Wembere Valley is a drainage system made up of the Manonga River basin in the northern part, and the Wembere Swamp basin in the south (Figure 1). The two systems empty their water into Lake Kitangiri. The valley is located within latitudes $3^{\circ} 30^{\prime} \mathrm{S}$ and $4^{\circ} 30^{\prime} \mathrm{S}$ and longitudes $33^{\circ} 00^{\prime} \mathrm{E}$ and $34^{\circ} 15^{\prime} \mathrm{E}$ in Central Tanzania. In this valley, Tertiary-Quaternary climatic and environmental changes have been studied by observing paleolake shoreline regression and transgression cycles. These cycles have indicated great extensions and reduction of fresh water conditions (Stockley 1947; Barth 1989). In addition, changes of sedimentation regimes from fine to coarse facies over long distances and faunal variation have also indicated climatic variations (Williams and Eades 1939; Handely 1956; Van Damme and Gautier 1997).

Verniers (1997) observed paleosol levels in Manonga-Wembere Valley lithosequences, and Mutakyahwa (1997) studied the mineralogical composition of some of the paleosols and observed weathering product-minerals, including paragonite and montmoril-

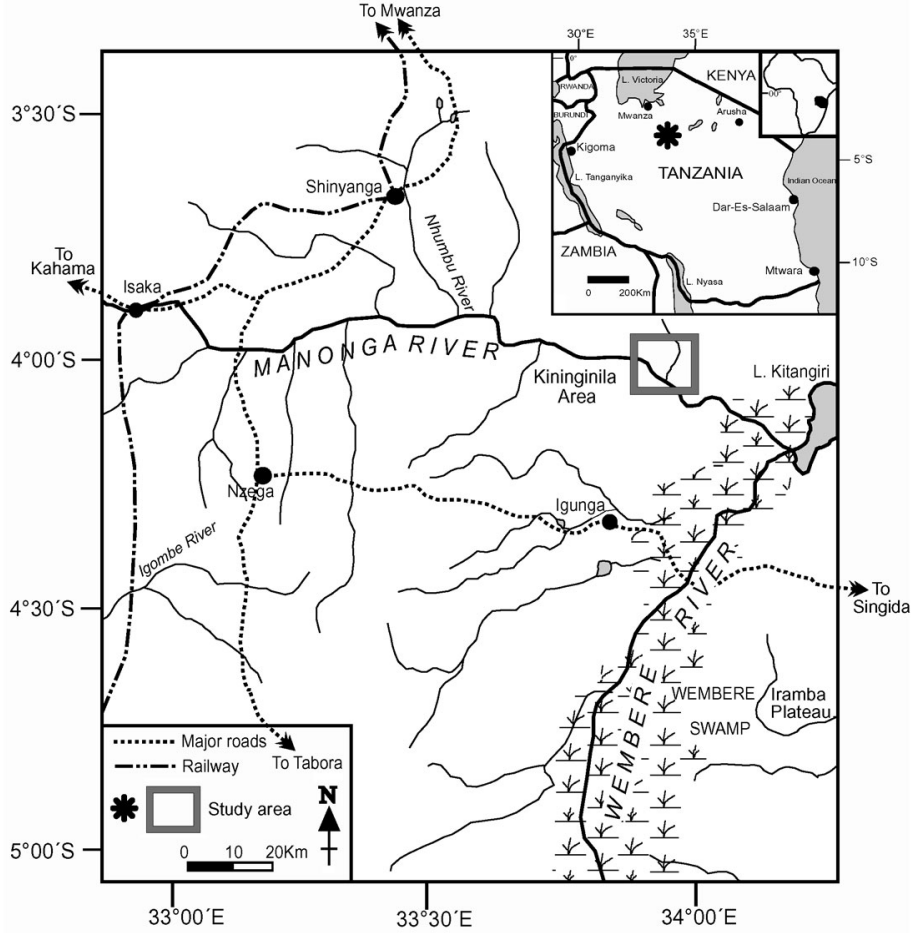

Figure 1 Location map of the Kininginila locality in the Manonga-Wembere Valley.

lonite, but the pedogenic aspects have not been studied. Paleosol characteristics and positions in stratigraphic successions are indicators of paleoclimatic fluctuations (Mahaney, 1980; Retallack, 1990; Paepe and Van Overloop, 1994; Kafumu, 2000; Ashley and Drissie, 2002). Here I report the stratigraphic succession of Kininginila section with its associated four paleosol levels in the Manonga River basin. The micromorphological characteristics of the paleosols are studied and their paleoclimatic implications are briefly discussed.

\section{Geological setting}

The Manonga-Wembere Valley is underlain by Nyanzian rock of Archaean age (2.7 Ga; Figure 2 ). The rocks are composed of weakly metamorphosed acidic and basic rocks, schistose metasediments and banded iron formations (Stockley, 1947; Verniers, 1997).

Igneous intrusions into the Nyanzian rocks represent granitization episodes during the Archaean. Their composition includes granites, gneissose-granites and migmatites (Stockley, 1947; Harrison, 
and Mbago 1997). At the end of the Miocene the Nyanzian rocks were subjected to peneplanation followed by downwarping of the Manonga Valley and faulting that developed the Wembere depression (Stockley, 1947). The processes created a shallow lake basin

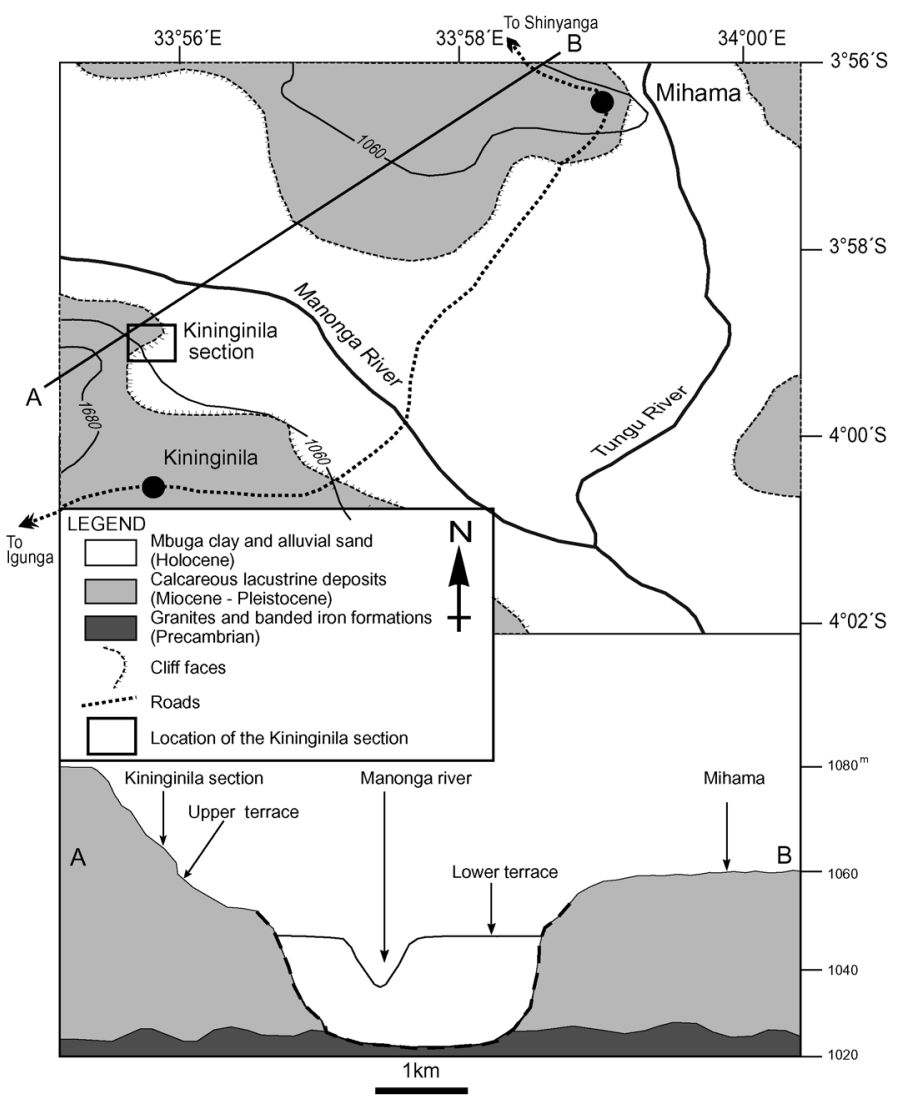

Figure 2 The geology of Kininginila locality in the ManongaWembere Valley.

\begin{tabular}{|c|c|c|c|c|}
\hline \multicolumn{2}{|c|}{$\begin{array}{l}\text { Stratigra } \\
\text { phic unit }\end{array}$} & Characteristic fossils & \multirow{2}{*}{$\begin{array}{l}\text { Age } \\
\text { (Ma) } \\
\mathbf{- 4 . 0}\end{array}$} & $\begin{array}{l}\text { Section } \\
\text { studied }\end{array}$ \\
\hline : & 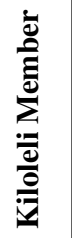 & $\begin{array}{l}\text { Damalacra sp. (Bovidae) } \\
\text { Tecktonomys africanus (Rodentia); } \\
\text { Thryonomys sp. (Rodentia); } \\
\text { and Anancus kenyensis } \\
\text { (Proboscidea, Gomphotheriidae). }\end{array}$ & & 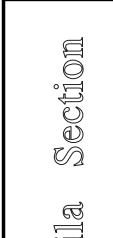 \\
\hline \multirow{2}{*}{ 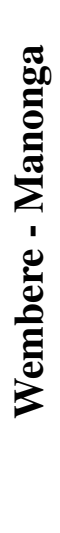 } & 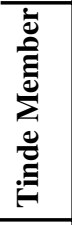 & $\begin{array}{l}\text { Kobus aff. subdolus (Bovidae); } \\
\text { Sivatherium sp.(Giraffidae); and } \\
\text { Nyanzacoerus kanamensis (Suidae). }\end{array}$ & -4.5 & 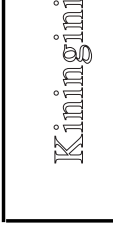 \\
\hline & 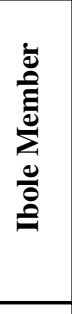 & $\begin{array}{l}\text { Stegotetrabelodon } \mathrm{sp} . \\
\text { (Proboscidea, Elephantidae); } \\
\text { Primelephas gomphotheroides } \\
\text { (Proboscidea, Elephantidae); } \\
\text { Hexaprotodon havardi } \\
\text { (Hippopotamidae) } \\
\text { Eurygnathohippus cf. turkanense } \\
\text { (Equidae) }\end{array}$ & -5.5 & \\
\hline
\end{tabular}

Figure 3 The chronostratigraphic scheme of the Manonga Wembere lacustrine deposits based on biochronological data (after Harris and Baker, 1997). that resulted in the deposition of lacustrine siltstone, mudstone, limestone, marls, calcareous clays, sand, gravel and conglomerate.

The conglomerates that form the base of the deposits lay unconformably on the Precambrian Nyanzian rocks marking the beginning of the Tertiary-Quaternary deposits of the Manonga-Wembere area. Paleosol levels that developed on the lake sediments during periods of lake regression and transgression intercalate the lacustrine deposits (Verniers, 1997; Kafumu, 2000). The Late Quaternary (Upper Pleistocene to Holocene) was dominated by the carving of the Manonga River basin, which was later filled with mbuga clays and alluvial sands during the Holocene.

The Manonga-Wembere deposits are poorly dated due to the lack of datable volcanic materials. The only dates available are based on stratigraphic correlations and place the deposits within Late Pliocene through Pleistocene to Holocene (3 Ma - 0.0 Ma) (Williams and Eades 1939; Quennel et. al., 1956; Pickering, 1958; Barth, 1989). However, Harrison and Mbago (1997) and Harris and Baker (1997), based on paleontological evidence, estimate these lacustrine deposits to have an age of between 5.5 Ma and 0.0 Ma (Late Miocene to Holocene). Moreover, the Manonga-Wembere volcanic components that were reported by Mutakyahwa (1997) may provide a numerical age for the deposits. Based on the biostratigraphic studies of Harrison and Baker (1997) and Harrison and Mbago (1997) the Manonga - Wembere Formations are therefore divided into three stratigraphic members: the Ibole Member (5.5 Ma - 5.0 Ma); Tinde Member (5.0 $\mathrm{Ma}$ - 4.5 Ma); and Kiloleli Member (4.5 Ma - 4.0 Ma) (Figure 3). These stratigraphic boundaries are defined based on mammal fossil correlations. The temporal range of mammalian taxa found in these stratigraphic Members are comprised of Miocene-Pliocene mammals as summarized in Figure 3. Based on this biochronological data, the Kininginila section is restricted to the Lower Pliocene (5.0 $\mathrm{Ma}-4.0 \mathrm{Ma}$ ); a 1 million year interval. The section covers the two upper Members (Tinde and Kiloleli).

\section{Methods}

Detailed geological mapping was conducted around the Kininginila area. A systematic vertical lithological study on the Kininginila section was undertaken to map the different lithological units. These units were measured, described and photographed.

Four undisturbed paleosol samples were taken from the section for microscopic examinations. Samples were collected as hardindurated blocks of paleosols that were chipped off from the wall section. Thin sections were produced and described at $10 \mathrm{x}-400 \mathrm{x}$ magnifications under a polarizing transmitted light microscope, as per standard methods and using the terminology of Bullock et al., (1985) and Stoops (1998). Paleosol colour determinations and measurements were done according to the US Department of Agriculture (1975) standard methods of describing paleosols and soils.

\section{Results and discussion}

\section{Geology and stratigraphy}

The geology of the Manonga - Wembere Valley exposed at the Kininginila locality (latitudes: $3^{\circ} 56^{\prime} \mathrm{S}-4^{\circ} 02^{\prime} \mathrm{S}$; longitude: $33^{\circ} 56^{\prime} \mathrm{E}-$ $34^{\circ} 00^{\prime} \mathrm{E}$ ) comprises the upper terrace, which is composed of calcareous lacustrine deposits, and the lower terrace composed of Holocene Mbuga clay and sand deposits. The upper terrace of the valley exposes the older sediments and is the remnant of the infilled Miocene-Pliocene-Pleistocene Manonga-Wembere paleolake. This study presents the stratigraphic section of the Kininginila locality in which four paleosol levels were studied. The section covers the middle (Tinde) and upper (Kiloleli) Members of the Manonga-Wembere Formation, and represents a one-million years interval of the Lower Pliocene (5.0 Ma-4.0 Ma). The Kininginila section stratigraphic column is presented in Figure 4. The section is about $21 \mathrm{~m}$ thick. The 
section begins with gray calcareous clay containing two gravel beds. This unit is overlain by a reddish brown paleosol (GS 4). Overlying the paleosol is a whitish gray nodular clay level containing calcareous nodules. A white sandy silt lies conformably on the nodular clay level. The silt is followed by layered reddish clay sediments, which grade into dark gray clay. The dark gray clay is then overlain successively by a reddish brown paleosol (GS 3) and a red paleosol (GS2). The upper paleosol is then covered by grayish white clay silt followed by another reddish pink paleosol (GS1). A grayish white silty mud caps this sequence. The upper part of the section is a series of pale yellow clay and dark layered clay levels lying unconformably on the silty mud in succession. The sequence is capped by dark gray calcareous soil.

Mammal fossil remains in Manonga-Wembere deposits are found often occurring on the surface or within paleosols or close to paleosol levels (Harrison and Mbago, 1997). This implies that the paleosols are key horizons in mapping fossil rich zones in the Manonga-Wembere Valley. These paleosols were formed during regression cycles of the Manonga-Wembere paleolake and may have been living floors of the animals. The animal fossils found in the Manonga-Wembere Formation are mainly Pliocene mammals, including mammal species like bovidae, rodentia, proboscidea (like gomphotheriidae and elephantidae), hippopotamidae, equidae, giraffidae and suidae (Figure 3). These animals indicate a wet paleoecol- ogy during the Lower Pliocene in the area (Harrison, 1997; Harrison and Baker, 1997).

\section{Paleosol micromorphological characteristics}

In the Kininginila section four red to red brown paleosol levels (GS1, GS2, GS3 and GS4) and one modern soil (GS0) have been observed (Figure 5). The micrograph (Figure 6a) from the thin section of paleosol GS1 indicates micromorphological characteristics with typic red to yellow clay coating on voids (ycv) in a yellow argillic groundmass. The micrograph of paleosol level GS2 (Figure $6 \mathrm{~b})$ shows a red fabric consisting of an accumulation of red to yellow clay coating fragments (rcf). This accumulation of clay coating fragments indicates evidence of stress in the paleosol probably due to turbation. The micrograph obtained from paleosol GS3 (Figure 6c) shows typic yellow clay coating on channels (ycc) in an argillic red groundmass. The paleosol GS4 micrograph (Figure 6d) shows a fabric consisting of a turbated accumulation of yellow clay coating fragments (ycf). There are some $\mathrm{Fe}-\mathrm{Mn}$ hydroxide hypocoatings in channels (fmh). It is important to note that in all the micrographs there is no calcite in the pedofeatures and in the groundmass. The important field and micromorphological characteristics of the paleosols are summarized in Table 1.

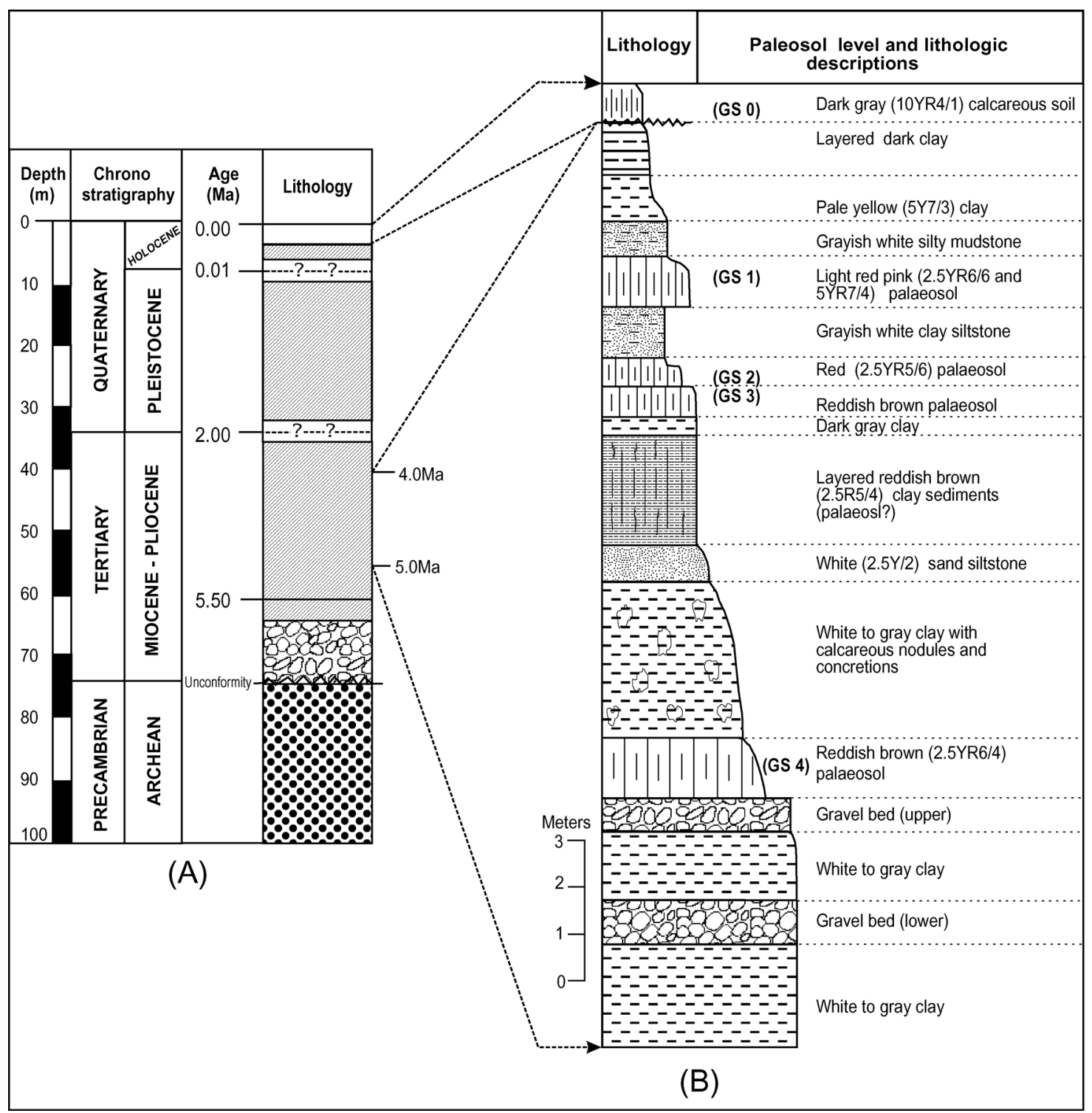

Figure 4 The general stratigraphic column of Manonga-Wembere deposits (A) and the chronostratigraphic column of Kininginilla section $(B)$. 


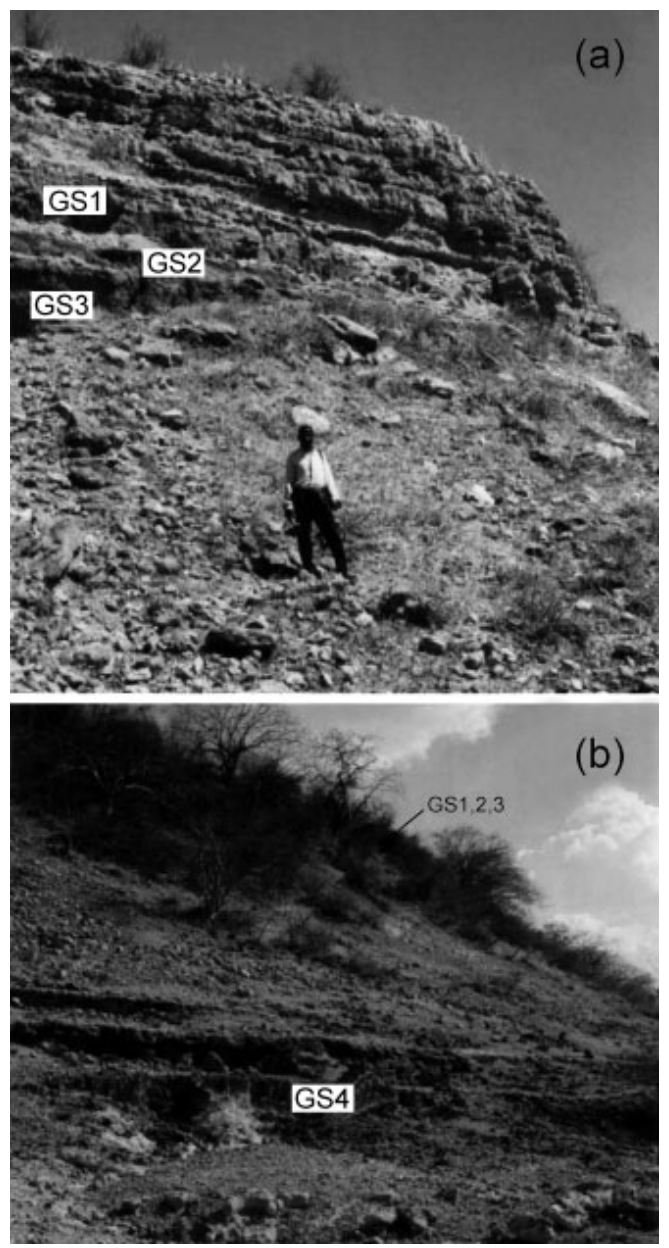

Figure 5 The upper terrace of the Kininginila section showing red horizons that represent paleosol levels GS1, GS2 and GS3 (above) ansd GS4 (below).

\section{Paleoclimatic implications}

In summary, the micromorphological characteristics of the Manonga - Wembere paleosols show red to yellow clay coating and hypocoating in voids and channels and some Fe-Mn hydroxide hypocoating in voids (Figure 6). The groundmass fabric is either an accumulation of yellow clay coating
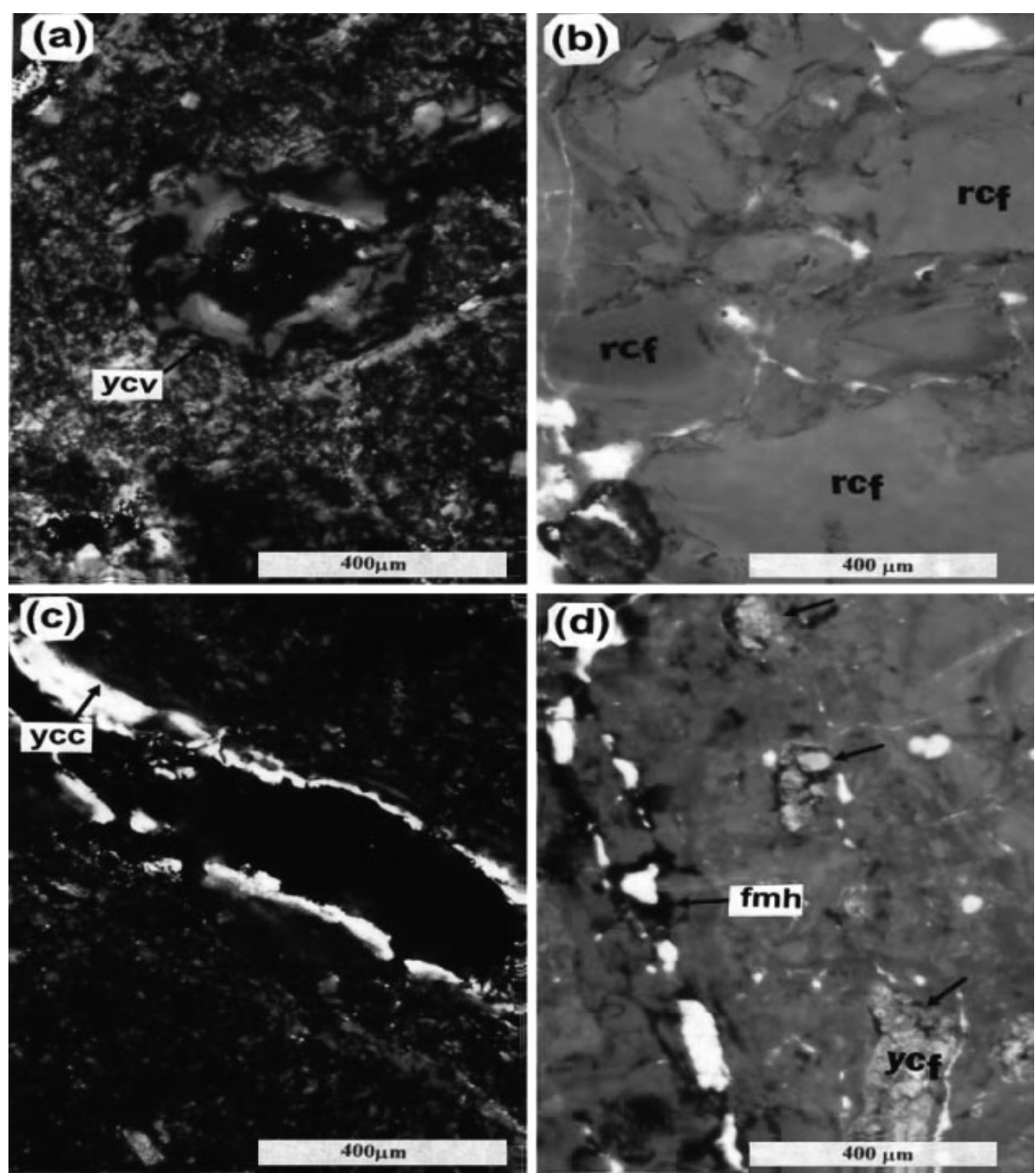

Figure 6 Micrographs indicating the micromorphological characteristics of paleosol levels (a) GS1: Strongly oriented yellow clay coating and hypocoating on pore and channels; (b) GS2: Red clay coationg fragments (rcf) constituting a groundmass that shows sign of stress in the paleosol; (c) GS3: Typical yellow clay coating on channels and voids and (d) GS4: Yellow clay coating fragments (ycf) in a turbated yellowish red groundmass and Fe-Mn hydroxide hypocoating in a chain of parallel channels (note the parallel alignment-orintation of the clay coating fragments to the channel).

fragments or an argillic yellow to red clay mass. Calcite was not observed in the pedofeatures and in the groundmass .

The yellow and red clay illuviation (yellow and red clay coating and clay coating fragments) accompanied by the absence of calcite

Table 1 Important characteristics of the studied paleosol levels from the Kininginila section

\begin{tabular}{|c|c|c|c|c|}
\hline $\begin{array}{c}\text { Paleosol } \\
\text { level }\end{array}$ & $\begin{array}{l}\text { Depth/thickness } \\
\text { (meters) }\end{array}$ & Lithology & $\begin{array}{c}\text { Colour } \\
\text { description }\end{array}$ & Pedofeatures \\
\hline GS0 & $0.0-0.55$ & $\begin{array}{l}\text { Layered } \\
\text { clay }\end{array}$ & $\begin{array}{l}\text { Dark gray (10YR4/1) } \\
\text { present soil }\end{array}$ & -Active root activity and peds \\
\hline GS1 & $4.5-7.0$ & Clay & $\begin{array}{l}\text { Light red (2.5 YR6/6) } \\
\text { showing red mottling }\end{array}$ & $\begin{array}{l}\text {-Red to yellow typic clay coating } \\
\text { and hypocoating on voids } \\
\text {-The groundmass is a yellow clay mass }\end{array}$ \\
\hline GS2 & $8.0-8.5$ & $\begin{array}{l}\text { Calcareous } \\
\text { clay }\end{array}$ & $\begin{array}{l}\text { Red }(2.5 \text { YR5/6) showing } \\
\text { gray mottling }\end{array}$ & -Red to yellow claycoating fragments \\
\hline GS3 & $8.5-9.0$ & $\begin{array}{l}\text { Layered } \\
\text { clay }\end{array}$ & $\begin{array}{l}\text { Reddish brown (2.5YR5/4) } \\
\text { showing gray mottling }\end{array}$ & $\begin{array}{l}\text {-Yellow typic clay coating on channels } \\
\text {-The groundmass is a red clay mass }\end{array}$ \\
\hline GS4 & $18.4-19.6$ & $\begin{array}{l}\text { Calcareous } \\
\text { clay }\end{array}$ & Reddish brown (2.5YR6/4) & $\begin{array}{l}\text {-Yellow clay coating fragments in a } \\
\text { turbated yellowish red groundmass. } \\
\text {-Fe-Mn hydroxide hypocoating } \\
\text { in channels. }\end{array}$ \\
\hline
\end{tabular}


and reddening of the groundmass in a predominantly gray calcareous clayey sediment is evidence of weathering under wet and humid climates. The presence of some Fe-Mn hydoxide coating in voids indicates a substantial hydromorphic regime during this time. The fabric indicates an intense illuviation front that is common in calcareous deposits in present day wet and warm climates. The four paleosol levels are found within a time interval of 1 million years $(5.0 \mathrm{Ma}-$ 4.0 Ma, Lower Pliocene). Paleosol levels 1 (GS1), 2 (GS2) and 3 (GS3) are close to one another (Figure 4) and may represent shorter cycles of probably 100 ka cyclicities within the 1 Ma time interval. Paleosol level 4 (GS4), below the other levels may have been formed between $400 \mathrm{ka}$ and $500 \mathrm{ka}$ years earlier, assuming a constant sedimentation rate.

The strong illuviation front in the paleosols of the ManongaWembere Valley represents humid climates during Lower Pliocene times. These paleosol levels therefore indicate stable landscapes that were probably more humid than today.

\section{Conclusions}

The Manonga-Wembere sediments were laid down in a paleolake basin that had earlier developed on the peneplaned Archaean Nyanzian rocks (granites and banded iron formation) during the Early Tertiary. The geology of the Kininginila locality in the Manonga Wembere Valley includes mainly lacustrine sediments (clay, calcareous clay, silt, mud, sand and gravel beds) of Pliocene age intercalated with paleosol levels. The paleosol levels are closely related to the occurrence of animal (mammals) fossil remains that have been found in the area.

The micromophological features of the paleosols show a strong illuviation with a dominance of red to yellow clay coating and clay coating fragments together with Fe-Mn hydroxide hypocoatings on channels and voids. The groundmass is an argillic fabric consisting of either an accumulation of yellow to reddish yellow clay coating fragments or a red to yellow clay mass. There is an absence of calcite in the pedofeatures. The strong clay illuviation and absence of calcite indicates that pedogenesis took place during a wetter climate in the Lower Pliocene than today.

\section{Acknowledgements}

The author is grateful to the Commissioner for Minerals of the Government of Tanzania for funding the fieldwork for this study. The Tanzania Commission for Science and Technology is acknowledged for granting research permits to work in the area. The author is also grateful to Prof. Georges Stoops of the Petrology, Mineralogy and Micropedology Laboratory of Ghent State University, Belgium for providing the laboratory analyses.

\section{References}

Ashley. G. M. and Driese, S. G., 2002. Paleopedology and paleohydrology of a volcanoclastic paleosol interval; Implications for Early Pleistocene stratigraphy and paleocliate record. Journal of Sedimentary Research 70(5), 1065-1080.

Barth, H., 1989. The Lake Victoria gold fields, Tanzania. Provisional Geological Map; 1:500,000; Hanover/Dodoma; with text book with colored map. $20 \mathrm{p}$.

Bullock, P., Fedroft, N., Jongerius, A., Stoops, G., Tursina, T. and Babel, U., 1985. Handbook for soil thin Section description; Waine Research Publications Wolverhampton UK. 152 p.

Handely, J. F. R., 1956. Geological map, Quarter Degree Sheet 28. (Nzega), Mwambiti South B 36/D1 scale: 1:125,000. The Geological Survey of Tanganyika Dodoma.

Harrison T., 1997. Introduction: Paleoecology and Taphonomy of Fossil Localities I the Manonga valley, Tanzania; In T. Harrison (ed), Neogene,
Paleontology of Manonga Valley, Tanzania; A window into evolutionary history of East Africa, Plenum Press, New York. pp 79-105,

Harrison T., and Baker E., 1997. Introduction: Paleontology and Biochroinology of Fossil localities in the Manonga valley, Tanzania; In T. Harrison (ed), Neogene, Paleontology of Manonga Valley, Tanzania; A window into evolutionary history of East Africa, Plenum Press, New York. pp 361-393.

Harrison T., and Mbago, M. L., 1997. Introduction: Paleotological and geological research in the Manonga valley, Tanzania; In T. Harrison (ed), Neogene, Paleontology of Manonga Valley, Tanzania; A window into evolutionary history of East Africa, Plenum Press, New York. pp 2-32.

Kafumu, P.D., 2000. The Quaternary stratigraphy and environments of Olduvai George-Tanzania; Based of fossil soils and related Dating, Ph.D. Thesis; at the Free Univesty of Brussels; Brussels, Belgium. 413 p.

Mahaney, W. C., 1980. Paleoclimatic reconstruction from paleosol; Evidence from rocky mountains and East Africa. In W. C. Mahaney (ed); Quaternary paleoclimates. GeoAbstract Ltd. Norwich. pp 227 - 247.

Mutakyahwa, M.K.D., 1997. Mineralogy of Wembere-Manonga Valley; Tanzania, and possible provenance of the sediments. In T. Harrison. (ed), Neogene, Paleontology of Manonga Valley, Tanzania; A window into evolutionary history of East Africa, Plenum Press, New York. pp 67-78.

Paepe, R. and Van Overloop E., 1994. Mitigation of drought from global geological evidence. World Resource Review 6(4), 545-558.

Pickering, R., 1958. A Preliminary note on the Quaternary geology of Tanganyika; Joint meeting East Central, West-Central and Southern Regional Committee for Geology; Leopoldville. pp 77- 89.

Quennell, A.M, Mckilay, A.C. and Aitken, W. G., 1956. Summary of the Geology of Tanganyika, Part 1: Introduction and Stratigraphy; Memoir 1; pp264, Reprint, Government Printer 1986, Dar-es-Salaam, 264 p.

Retallack, G. J., 1990. Soils of the past: An introduction to palaeopedology. Unwin Hyman, London. 520 p.

Stockley. G.M., 1947. The geology of the country around Mwanza Gulf. Short paper; Geological Survey of Tanganyika, 29: 1-25.

Stoops, G., 1998. Guidelines for thin section description of regolith material; based on the "Handbook for soil thin section Description by Bullock", Course notes for international training Centre for Post-graduate Soil Scientists, (unpublished). Gent State University, Belgium. 180 p.

US Department of Agriculture, 1975. Munsell Soil Color Charts, 1975 edition; Munsell Color; McBeth Division of Kollmorgen Corporation, Baltimore, Maryland, USA. $18 \mathrm{p}$.

Van Damme, D. and Gautier, A., 1997. Late Cenozoic Fresh Water Mollusks of Wembere-Manonga Valley, Tanzania; In T. Harrison (ed), Neogene, Paleontology of Manonga Valley, Tanzania; A window into evolutionary history of East Africa, Plenum Press, New York. pp 351-360.

Verniers, J., 1997. Detailed Stratigraphy of the Neogene Sediments at Tinde and other localities in Central Manonga Basin: In T. Harrison (ed), Neogene, Paleontology of Manonga Valley, Tanzania; A window into evolutionary history of East Africa, Plenum Press, New York. pp 33-64.

Williams; G.J and Eades, N. W., 1939. Explanations of the Geology of Degree Sheet 19, (Shinyanga): Bulletin of the Geological Survey of Tanganyika 13; 5-20.

Kafumu P.D. received his PhD degree from the Free University of Brussels in Belgium in 2000. He has worked at the Geological Survey of Tanzania from 1983 until 2002, as a mineral exploration, mapping and environmental geologist. Since 2002 he is Head of Promotion and Statistics at the Ministry of Energy and Minerals responsible for the promotion of investment in the Tanzania's mineral sector. He is also undertaking research in stratigraphy and paleoclimatic reconstructions in the Tertiary-Quaternary basins of Tanzania. He is a member of the Geological Society of Africa and editor of the Tanzania Geological Society.

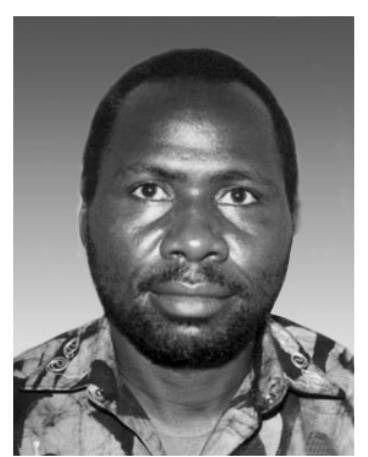

